\title{
PENERAPAN SISTEM INFORMASI MANAJEMEN DAERAH (SIMDA) KEUANGAN TERHADAP EFEKTIVITAS PELAPORAN KEUANGAN \\ (Studi pada Badan Pengelolaan Keuangan dan Aset Daerah Di Kabupaten Blitar)
}

\author{
Yogi Hertanto \\ Tjahjanulin Domai \\ Fadillah Amin \\ Jurusan Administrasi Publik, Malang \\ E-mail: yogihertanto93@gmail.com
}

\begin{abstract}
The presence of SIMDA of Finance is expected to be contribute towards the process of financial management, particularly at the stage of financial reporting should be able to running better. The ideal management information system is able providing a support to the process of planning, control and decision making. In addition the effectiveness of financial reportinghas to fullfil several criteria, which is reliable, accuracy / accurate, timely and report forms. This study was conducted to analyze the role of SIMDA towards the effectiveness of the financial reporting process, and the factors that influence it. This study uses qualitative data to describe and analyze objectives: Implementation of Regional Management Information System (SIMDA) of Finance toward the Effectiveness of Financial Reporting In Badan Pengelolaan Keungan dan Aset Daerah of Blitar Distric. Data was collected by using an interview, observation and documentation. Results from this study indicate that the SIMDA of Finance Aplication in the process of financial management, especially the financial reporting work better but still could not said to be fully effective, this is because of the presence of various obstacles are still fundamentally highly influential in the implementation SIMDA of Finance Aplication
\end{abstract}

Keywords: SIMDA, Management Information System, Effectiveness, Financial Reporting.

\section{PENDAHULUAN}

Semenjak diberlakukannya otonomi daerah di Indonesia, pemerintah daerah memiliki peranan sebagai organisasi sektor publik yang diberi kewenangan oleh pemerintah pusat dalam mengatur pemerintahannya sendiri. Kewenangan pemerintah daerah dalam pelaksanaan otonomi daerah diatur dalam dalam UndangUndang Nomor 23 Tahun 2014 tentang Pemerintahan Daerah. Dalam UndangUndang Nomor 23 tersebut dijelaskan bahwa pemerintah daerah diberi keleluasaan dalam mengatur maupun mengurus rumah tangga daerahnya sendiri, menetapkan kebijaksanaan sendiri serta melakukan pembiayaan dan pertanggungjawaban keuangan sendiri.
Otonomi daerah kemudian direfleksikan dengan adanya suatu desentralisasi, dimana terdapat tiga hal penting yang mempengaruhi terlaksananya desentralisasi dengan baik yaitu adanya penyerahan sumber pendanaan, sumber daya manusia (SDM) dan perangkat fisik yang memadahi guna mendukung pelaksanaan berbagai urusan yang diserahkan kepada daerah, termasuk dalam urusan pengelolaan serta pelaporan keuangan daerah. Kewenangan yang luas, utuh dan bulat pada akhirnya harus dipertanggungjawabkan kepada pemberi wewenang dan masyarakat.

Kebutuhan informasi akurat dan tepat waktu pada tahap pengambilan keputusan secara tidak langsung memberikan stimulus 
kepada banyak organisasi akan kebutuhan sistem informasi yang rensposif terhadap kebutuhan mereka hal tersebut sesuai dengan pendapatRahadi (2007, h.10). Kebijakan dalam rangka pemanfaatan teknologi dan informasi oleh Pemerintah Daerah telah diatur dalam PP No.56 Tahun 2005 Tentang Sistem Informasi Keuangan Daerah sebagai pengganti PP No.11 Tahun 2001 tentang Informasi Keuangan Daerah. Bentuk dari pemanfaatan teknologi dan informasi yaitu dengan diterapkannya aplikasi teknologi komputer sebagaisalah satu alat bantu pada proses akuntansi. Saat ini pemerintah kota serta pemerintah kabupaten telah mengimplementasikan sistem informasi keuangan daerah yang disediakan oleh BPKP atau Badan Pengawasan Keuangan dan Pembangunan khususnya produk dari (Deputi IV) yaitu Pengawasan Bidang Penyelenggaran Keuangan Daerah melalui pemanfaatan teknologi dan informasi yang terhubung langsung dengan database. Aplikasi itu adalah Sistem Informasi Manejemen Daerah (SIMDA), suatu aplikasi komputer yang merupakan salah satu dari komponen Sistem Akuntansi Pemerintah Daerah (SAPD) yang sediakan sebagai aplikasi pembantu Pemerintah Daerah pada sistem akuntansinya mulai dari menyelenggarakan hingga mempertanggungjawabkan pengelolaan keuangan daerah.

SIMDA Keuangan yang diterapkan di Kabupaten Blitar sampai saat ini sudah mencapai versi 2.7.0.6 sebagai penyempurna versi-versi yang terdahulu. Program aplikasi SIMDA sudah mencakup berbagai perundang-undangan yang berkaitan dengan pengelolaan keungan, yaitu seperti yang telah diatur dalam Undang-Undang Nomor 17
Tahun 2003 tentang Keuangan Negara, Undang-Undang Nomor 1 Tahun 2004 tentang Perbendaharaan Negara, dengan demikian pencatatan, pendokumentasian, maupun pelaporan yang dilakukan secara manual dialihkan pada sistem komputerasi yang telah terintegrasi kepada setiap SKPD.

Dalam implementasinya SIMDA pemerintah Kabupaten Blitar dalam proses pengelolaan keuangan daerahnya secara terintegrasi meliputi penganggaran, penatausahaan, akuntansi dan pelaporan. Proses penganggaran dapat berupa RKA, penjabaran APBD maupun perubahannya serta dokumen DPA, rancangan APBD. Proses penatausahaan sepertiSurat Perintah Membayar, Surat Penyediaan Dana dan juga Surat Permintaan Pembayaran atau SPP, kemudian beserta register-register dan berbagai formulir pengendalian anggaran lainnya. Sedangkan untuk kegiatan akuntansi dan pelaporan berupa jurnal, laporan keuangan, buku besa, perda pertanggungjawaban beserta penjabarannya dan laporan arus kas. Meskipun demikian ukuran keefektivan penggunaan SIMDA Keuangan sendiri masih belum banyak diketahui dengan pasti, sehingga akan menarik jika dapat dilakukan analisis mengenai hal tersebut guna memperoleh data terkait implementasi pelaporan keuangan dengan menggunakan SIMDA Keuangan.

Berdasarkan uraian diatas maka penulis kemudian merumuskan beberapa rumusan masalah yaitu Bagaimanakah perencanaan dan Penerapan Sistem Informasi Manajemen Daerah (SIMDA) Keuangan Daerah pada Pemerintah Kabupaten 
BlitardanBagaimanakah dampak dari penerapan system tersebut, kemudian berkaitan dengan Faktor apa sajakah yang mendukung dan menghambat penerapan SIMDA keuangan pada Pemerintah Kabupaten Blitar, serta bagaimana strategi dalam mengatasi hambatan tersebut. Tujuan dari penelitian ini adalah Menjelaskan terkait perencanaan dan penerapan SIMDA Keuangan pada pemerintah Kabupaten Blitar, Menjelaskan dampak penerapan SIMDA Keuangan terhadap efektifitas pelaporan keuangan pada pemerintah Kabupaten Blitar dan selanjutnya menjelaskan faktor-faktor yang mendukung dan menghambat penerapan SIMDA Keuangan pada pemerintah Kabupaten Blitar, serta strategi dalam mengatasi hambatan tersebut.

\section{KAJIAN PUSTAKA}

\section{Administrasi Pembangunan}

Administrasi Pembangunan menurut Siagian (1974, h.4) adalahserangkaian usaha yang dilakukan masyarakat guna memperbaiki tata kehidupannya sebagai suatu bangsa dalam berbagai aspek kehidupan bangsa, yang seluruhnya dilakukan dalam rangka usaha pencapaian tujuan yang telah ditentukan.

Kemudian Bintoro (1995) memberikan pendapat bahwa Administrasi pembangunan mempunyai tiga fungsi: Pertama adalahkebijakan penyempurna Administrasi negara Ini dapat disebut the development of Administration (pembangunan Administrasi), atau "Administrative Reform" (reformasi admnistrasi). Kedua, perumusan kebijaksanaan serta program pembangunan berbagai macam bidang juga pelaksanaannya yang efektif, disebut the Administration of development. Ketiga, adalah bagaimana cara untuk membangun partisipasi masyarakat dalam proses pembangunan.

\section{Sistem Informasi Manajemen (SIM)}

SIM adalah suatu perpaduan manusia dan berbagai sumber daya modal dalam organisasi yang bertanggung jawab pada proses pengumpulan dan pengolahan data agarmemberikan keluaran informasi yang memiliki manfaat dalam semua tingkatan manajemen seperti yang dikemukakan oleh Chusing dalam jogiyanto (1999, h.14)

SIM yang baik dapat berkontribusi pada proses-proses perencanaan, pengendalian serta proses pengambilan keputusan seperti yang telah banyak dibahas Sutanta (2003, h.43). SIM pada proses perencanaan adalah berbentuk dukungan analitik dan persamaan model, input data berlandaskan pada data historis serta kemampuan memanipulasi data melalui teknik peramalan serta ekstrapolasi. SIM pada tahap pengendalian berkaitan dengan analisis perbedaanantara prestasi dengan standar yang ada,. Menurut Sutanta (2003, h.50) SIM dalam pengambilan keputusan berkaitan dengan tiga hal yaitu Penelusuran masalah, desain pemecahan masalah, pemilihan serta pengujian cara dalam pemecahan permasalahan

\section{Sistem Informasi Manajemen Daerah (SIMDA)}

SIMDA merupakan salah satu produk dari penerapan prinsip e-Government yang mulai muncul saat diterbitkannya Instruksi Presiden Nomor 3 Tahun 2003 yaitu tentang Strategi Nasional Pengembangan eGovernment yang kemudian didukung oleh 
munculnya Permendagri Nomor 59 Tahun 2007 tentang Perubahan Peraturan Atas Peraturan menteri Dalam Negeri Nomor 13 Tahun 2006 yaitu tentang Pedoman Pengelolaan Keunagan daerahtentang Pedoman Pengelolaan Keunagan daerah. Sistem informasi manajemen ini dikembangkan guna memudahkan kegiatan satuan kerja dalam mengelola keuangan mereka, sehingga pada akhirnya pengelolaan keuangan satuan kerja tersebut menjadi lebih efektif, efisien dan ekonomis.

SIMDA Keuangan juga berlandaskan padaPermendagri No.55 Tahun 2008 tentang Penatausahaan dan Penyusunan Laporan Pertanggungjawaban Bendahara Serta Penyampaiannya dan juga berdasar pada Peraturan Menteri Dalam Negeri Nomor 55 Tahun 2008 yaitu tentang Penatausahaan dan Penyusunan Laporan Pertanggungjawaban Bendahara Serta Penyampaiannya. Dengan pertimbangan bahwa pemerintah merasa perlu adanya pengelolaan keuangan denganberlandaskan pada penyelenggaraan informasi yang seluas-luasnya, hal ini seperti tercantum dalam pasal 4 ayat 3 pada peraturan tersebut.

\section{Laporan Keuangan Daerah}

Laporan keuangan merupakan laporan yang memuat data maupun informasi keuangan suatu organisasi. Laporan keuangan merupakan hasil proses akuntansi yang diperuntukan sebagai sarana transfer informasi keuangan terutama kepada lingkungan luar organisasi(eksternal). Menurut Soemarsono (2004, h.34)Laporan keuangan dirancang untuk para pembuat keputusan (decicion maker), terutama pihak diluar lingkungan perusahaan, mengenai bagaimana posisi keuangan serta hasil pencapaian usaha suatu organisasi.

Sedangkan berdasar pada Peraturan Menteri Dalam Negeri Nomor 13 Tahun 2006, tentang Pedoman Pengelolaan Keuangan Daerah, dalam ketentuan umumnya menyebutkan bahwa yang dimaksud dengan keuangan daerah merupakan bagian dari seluruh hak ataupun kewajiban daerah dalam urusan penyelenggaraan pemerintahnya yang dinilai dengan uang maupunsemua bentuk kekayaan yang berkaitan terhadap semua hak maupun kewajiban daerah tersebut.

\section{Simda dan Efektifitas Laporan Keuangan Daerah}

Indikator efektivitas merupakan jangkauan dampak dari suatu program dalam mencapai tujuan program itu sendiri. Semakin besar kontribusi suatu program (Output) yang dihasilkan terhadap pencapaian maupun sasaran yang telah ditentukan, maka akan semakin efektif pula proses kerja unit organisasi tersebut. Seperti yang diungkapkan Gibson dalam Satries (2011, h.33), efektivitas terbagi dalam tiga bentuk, yaitu: [a] Efektivitas individu, adalah tingkatan efektivitas paling dasar dimana hal yang paling ditekankan berkaitan dengan hasil karya individu tertentu dalam sebuah organisasi; [b] Efektivitas kelompok yaitu efektivitas yang lebih menekankan kontribusi dari keseluruhan anggotanya; dan [c] Efektivitas organisasi yaitu gabungan antara efektivitas kelompok serta efektivitas individu sehingga bersatu dan menghasilkan output yang lebih tinggi tingkatannya. 
Kemudian Agar laporan keuangan relevan dan efektif, maka sumber datanya harus dapat dipercaya, akurat, tepat waktunya dan disajikan dalam bentuk-bentuk yang cocok bagi setiap tingkat manajemen. Oleh karena itu dalam memenuhi tujuan laporan keuangan, proses tersebut haruslah dikembangkan dengan baik khususnya pada setiap tingkatan manajemen di seluruh organisasi. Sebagaimana menurut Hamilton (1985, h.6) Laporan keuangan yang efektif memerlukan kriteria: 1) Dapat dipercaya, 2) Ketepatan, 3) Tepat waktu, 4) Bentuk-bentuk laporan

\section{METODE PENELITIAN}

Penelitian ini merupakan jenis penelitian deskriptif melalui pendekatan yang bersifat kualitatif. Pendekatan kualitatif peneliti gunakan dalam penelitian ini dengan alasan karena permasalahan yang diteliti kompleks, dinamis dan memiliki berbagai makna sehingga tidak dimungkinkan data yang ada pada situasi tersebut diintepretasikan kedalam pendekatan penelitian kuantitatif. Pengertian kualitatif secara definitif amatlah beragam, seperti yang dijelaskan oleh Taylor dalam Moeleong (2006) bahwasannya metode kualitatif merupakanpenelitian yang memiliki output atau keluaran berbentuk data deskriptif berupa kata-kata yang tertulis maupun berbentuk lisan yang diperoleh melaluinarasumber, kemudian perilaku yang mampu untuk diamati. Penelitian deskriptif berorientasi pada masalah-masalah dalam lingkunganbermasyarakat, dan tatacara yang berlaku dalam lingkungan masyarakat serta keadaan-keadaa tertentu, termasuk tentang bagaimana hubungan antar kegiatan, pandangan-pandangan, sikap-sikap, serta proses yang sedang berjalan dan pengaruh yang diberikan dari suatu peristiwa hal ini seperti yang dikemukakan oleh Mukhtar (2013).

Lokasi penelitian beradapada Kabupaten Blitar yang tepatnya mengambil data dan informasi dari fenomena yang terjadi pada Badan Pengelolaan Keuangan dan Aset Daerah Kabupaten Blitar, yang ber alamat J1. WR. Soepratman No. 09 Telp. (0342) 801596 Blitar

Sumber data penelitian ini diperoleh dari data primer dan data sekunder. Pengumpulan data dilakukan melalui proses wawancara, observasi serta dokumentasi. Analisis data penelitian ini menggunakan metode QDA (Qualitative Data Analysis) oleh Seidel (1998, h.2)

\section{PEMBAHASAN}

Proses Perencanaan dan Penerapan Sistem Informasi Manajemen Daerah (SIMDA) Keuangan Daerah: di Pemerintah Kabupaten Blitar

Proses pelaksanaan SIMDA Keuangan terkait perannya dalam Administrasi yaitu mencakup pengumpulan data keuangan, perencanaan anggaran, pertanggungjawaban serta pelaporan anggaran. Sehingga jika dikaitkan dengan apa yang diungkapkan Badan Pengawasan Keuangan dan Pembangunan (2013, h.2) bahwasannya SIMDA Keuangan mencakup penganggaran, penatausahaan, dan pelaporan maka dari itu telah terjadi kesesuaian didalamnya. Di dalam aplikasi SIMDA Keuangan sudah dapat menjalankan prosedur Administrasi keuangan 
mulai dari proses penganggaran hingga pelaporan, serta hal-hal yang mendasar berkaitan dengan Tupoksi (Tugas Pokok dan Fungsi) seperti perincian program anggaran yang digunakan dan lain-lain.

Berdasarkan hasil tersebut dapat dipahami bahwa SIMDA Keuangan memberikan dampak terhadap kemudahan pengelolaan keuangan termasuk didalamnya pelaporan keuangan, adanya efisiensi terkait waktu dan prosedur pengelolaan keuangan yang secara langsung akan berkaibat pada tercapainya tujuan suatu organisasi, dimana SIMDA Keuangan memiliki peran dalam membantu individu dalam melakukan pekerjaannya dimulai dari tingkatan manajem bawah hingga individu pada tingkat manajemen atas yaitu pimpinan dalam pengambilan keputusan, diaman keputusan sangat berpengaruh kepada efektivitas suatu organisasi, sehingga hal tersebut sesuai dengan pendapat Gibson dalam Satries (2011, h.33) bahwa efektivitas terbagi menjadi tiga yaitu efektivitas individu, efektivitas kelompok, dan efektivitas organisasi.

\section{Dampak Penerapan Sistem Informasi} Manajemen Daerah (SIMDA) Keuangan Daerah pada Pemerintah Kabupaten Blitar

Berdasarkan hasil pembahasan terkait efektifitas SIMDA Keuangan yang telah dilakukan bahwa SIMDA Keuangan sebagai suatu Sistem Informasi Manajemen mendukung tiga hal utama, pada proses perencanaan, pengendalian serta pengambilan keputusan menurut Sutanta (2003, h.43). Secara garis besar SIMDA Keuangan memberikan kontribusi terhadap ketiga proses tersebut yang kemudian berdampak pada tercapainya tujuan suatu organisasi, dalam penelitian ini yaitu berkontribusi terhadap proses pengelolaan keuangan terutama pada proses pelaporan keuangan, dengan adanya SIMDA Keuangan ketiga proses tersebut berjalan lebih mudah dan lebih efektif, hal ini dapat dihubungkan dengan pendapat yang dikemukakan Ulum (2012, h.28) bahwa efektifitas merupakan ukuran berhasil atau tidaknya suatu organisasi dalam mencapai tujuan yang ingin dicapai. Apabila organisasi berhasil mencapai tujuannya maka organisasi tersebut dapat dikatakan telah berjalan secara efektif. Hal paling penting yang perlu dicatat yaitu bahwa efektifitas tidak hanya menyatakan tentang berapa besar biaya yang digunakan dalam pencapaian tujuan. Efektivitas hanya memandangbagaimana program dan kegiatan tersebut sudah mencapai tujuan yang telah ditetapkan.

Mendukung pendapat tersebut Widodo dalam Suranto (2007, h.27) juga menjelaskan bahwa efektivitas berarti dapat menyelesaikan tugas-tugas yang diserahkan dan dapat dikatakan efektif apabila dapat mencapai tujuan dan sasaran. Ukuran keefektivan yang telah dibahas hanya sebatas perbandingan dengan teori efektifitasyang ada dengan tujuan menjawab prinsip efektifitas yang diharapkan, namun belum di telaah lebih lanjut berdasarkan faktor-faktor penghambat yang ada dilapangan, terkait pembahasan faktor-faktor yang mempengaruhi pelaksanaan SIMDA Keuangan kemudian akan dibahas pada bagian pembahasan selanjutnya. 
SIMDA Keuangan terhadap Laporan Keuangan yang Efektif

Laporan keuangan dikatakan relevan dan efektif, haruslah memenuhi kriteria data dapat dipercaya, akurat, tepat waktunya dan disajikan dalam bentuk-bentuk yang cocok bagi setiap tingkat manajemen. Oleh karena itu dalam memenuhi tujuan laporan keuangan, proses tersebut harus dikembangkan dengan baik pada setiap tingkatan manajemen di seluruh organisasi. Kemudian, Menurut Hamilton (1985, h.6) bahwasannya Laporan keuangan yang dikategorikan efektif harus termasuk dalam beberapa kriteria yaitu : 1) Dapat dipercaya, 2) Ketepatan, 3) Tepat Waktu dan 4) Bentukbentuk Laporan. Yang kemudian akan dijelaskan sebagai berikut,

a. Dapat dipercaya

Dari hasil penelitian diperoleh hasil bahwa laporan yang dihasilkan melalui SIMDA Keuangan selama ini dapat dipercaya, sesuai dengan hasil pemaparan narasumber bahwa terdapat proses verivikasi ataupun pembahasan yang dilalui sebelum dilakukan pencairan, sehingga secara bersamaan laporan keuangan telah sesuai mengingat jika terjadi kesalahan pasti telah terdeteksi pada saat dilakukannya verivikasi terkait pencairan aliran dana.

b. Ketepatan

Jika ditelaah dari ketepatan bentuk laporan keuangan terkait format dan bentuk laporan maka SIMDA Keuangan sudah memenuhi itu mengingat SIMDA Keuangan telah mengacu pada peraturan dan standar akuntansi pemerintah yang berlaku.Salah satu proses yang dilalui adalah di sebut rekonsiliasi yaitu pencocokan data-data transaksi yang ada.

c. Tepat waktu

Diterapkannya SIMDA Keuangan ini maka runtutan proses penganggaran hingga penyusunan laporan keuangan menjadi lebih tepat waktu dan ringkas, ini dikarenakan sistem SIMDA Keuangan bersifat otomatis sehingga data hanya perlu satu kali entry kemudian data tersebut dapat dipergunakan untuk keperluan lainnya.

d. Bentuk-bentuk laporan

Berdasar pada hasil pengamatan bahwa di dalam SIMDA Keuangan, laporan keuangan mampu ditampilkan dalam bentuk yang sesuai dengan format yang telah memenuhi semua kriteria didalam Permendagri 13 tahun 2006 dan Permendagri no. 59 tahun 2007, juga telah sesuai seperti format Standar Akuntansi Pemerintah yang tertuang pada PP No. 24 tahun 2005.Hasil penelitian SIMDA Keuangan memenuhi apa yang tertera dalam Perbub Kabupaten Blitar No.30 Tahun 2014 tentang Kebijakan Akuntansi Pemerintah Kabupaten Blitar bahwa Komponenpenyusun yang terdapat pada satu set laporan keuangan yaituterdiri dari laporan pelaksanaan anggaran (budgetary reports) maupun berbagai laporanfinansial lainnyaseperti LRA, LAK, CALK dan lain-lain

Faktor-Faktor Pendukung dan Penghambat Penerapan Sistem Informasi Manajemen Daerah (SIMDA) Keuangan Daerah pada Pemerintah Kabupaten Blitar

a. Faktor Pendukung

Diterapkannya SIMDA Keuangan di Badan Pengelolaan Keuangan dan Aset 
Daerah Kabupaten Blitar juga tidak terlepas dari faktor-faktor yang mendukung hal tersebut diantaranya yang pertama terdapat landasan hukum yang jelas. Pemerintahan Kabupaten Blitar, yaitu khusunya Badan Pengelolaan Keuangan dan Aset Daerah Kabupaten Blitar telah memiliki sumber peraturan yang jelas melandasi terhadap pengimplementasian program aplikasi SIMDA Keuangan. Kedua, adanya dukungan sarana dan prasaran pelaksana SIMDA Keuangan yang memadai, ketersediaan sarana dan prasarana sangatlah penting dalam pelaksanaan suatu kegiatan dalam organisasi guna memeperlancar pelaksanaan kegiatan tersebut, sebagaimana teori efektifitas yang disampaiakan oleh Siagian (1978, h.77) bahwasannya terdapat satu point penting yaitu tersedianya sarana dan prasarana,

Ketiga, terkait adanya dukungan pendanaan guna pemenuhan sarana dan prasaran. Berdasarkan hasil penelitian diperoleh informasi bahwa setiap satuan kerja perangkat daerah telah menerima rekomendasi BPKAD selaku Admin SIMDA Keuangan yaitu untuk melakukan penganggaran dalam APBD SKPD guna pemenuhan fasilitas pengoperasian yang memadai.

b. Faktor Penghambat

Dalam pelaksanaannya juga terdapat faktor yang dianggap secara mendasar menghambat kelancaran pelaksanaan SIMDA Keuangan yaitu belum terintegrasi dengan seluruh SKPD secara online, sehingga pemindahan data-data keuangan masih dilakukan dengan cara manual, kemudian kurang fleksibelnya aplikasi SIMDA Keuangan sehingga seluruh perbaikan sistem aplikasi hanya bisa menunggu respon dari BPKP selaku pengembang program SIMDA Keuangan dan yang terakhir permasalahan sumber daya manusia selaku operator yang masih belum maksimal dalam pengoperasian SIMDA Keuangan.

\section{KESIMPULAN}

SIMDA Keuangan telah terlaksana dengan baik, namun dalam pelaksanaanya masih terdapat beberapa hambatan yang sangat berpengaruh dalam proses pelaksanaan SIMDA Keuangan sehingga masih belum cukup untuk dikatakan bahwa pelaksanaan SIMDA Keuangan di Kabupaten Blitar telah berjalan secara efektif.Kemudian jika dikaitkan dengan teori yang dikemukakan oleh Gibson bahwa efektifitas dibagi menjadi 3 yaitu efektifitas individu, kelompok, dan organisasi, maka proses pelaksanaan SIMDA Keuangan di Kabupaten Blitar termasuk pada tingkatan efektifitas kelompok, SIMDA Keuangan belum dapat dikatakan memberikan dampak efektif pada lingkup organisasi kepemerintahan Kabupaten Blitar, melainkan hanya pada batasan tingkatan kelompok yaitu SKPD hal ini terjadi karena masih terdapat hambatanhambatan yang sangat signifikan.

Berdasarkan hasil pembahasan dan kesimpulan yang telah dipaparkan sebelumnya, maka bertujuan guna meningkatkan kualitas penerapan SIMDA Keuangan terhadap pelaporan keuangan di BPKAD Kabupaten Blitar sehingga peneliti memberikan saran-saran yaitu sebagai berikut:

1) Melakukan pengintegrasian secara online seluruh satuan kerja (SKPD) pengguna 
SIMDA Keuangan dalam lingkup Kabupaten Blitar, telah diketahui hal ini akan dilaksanakan pada tahun 2016, sehingga dirasa perlu adanya pengendalian yang kuat, dan memiliki prosedur pengamanan yang baik.

2) Meningkatkan koordinasi dan menjalin hubungan baik antara BPKAD dengan BPKP sehingga proses feedback dan respon perbaikan akan selalu terjangkau dengan baik dan cepat.

3) Meningkatkan kualitas pelatihan, sosialisai, maupun bimtek yang dilakukan BPKAD dan juga BPKP yang mana diharapkan akan terus menambah pemahaman terkait SIMDA Keuangan itu sendiri.

\section{DAFTAR PUSTAKA}

Bintoro, Tjokroamidjojo. (1995). Pengantar Administrasi Pembangunan. Jakarta: LP3ES.

Jogiyanto, Hartono. (1999). Analisis Dan Disain Sistem Informasi: pendekatan terstruktur teori dan praktek aplikasi bisnis. Yogyakarta: Andi

Moleong, Lexy. (2006). Metodologi Penelitian Kualitatif. Bandung: PT. Remaja Rosdakarya.

Mukhtar. (2013). Metode Praktis Penelitian Deskriptif Kualitatif. Jakarta: GP Press Group.

Rahadi, Dedi Rianto. (2007). Peran Teknologi Informasi dalam Peningkatan Pelayanan Sektor Publik.. Jurnal Seminar Nasional Teknologi 2007 (SNT 2007) ISSN : 1978 9777, Yogyakarta.
Satries, W.I. (2011). Efektivitas Program Pmeberdayaan Pemuda pada Organisasi Kepemudaan Alfatih Ibadurrohman Kota Bekasi. Tesis. Universitas Indonesia,Salemba.

Seidel, John V. (1998). Paper :Qualitative Data Analysis. Colorado Springs, Colorado: Qualis Research.

Siagian S. P, (1974), Administrasi Pembangunan, Jakarta: Gunung Agung

Siagian. (1978). Peranan Staf dan Managemen. Jakarta: Gunung Agung.

Soemarsono, S.R, 2004. Akuntansi: Suatu Pengantar. Edisi Kelima, Buku 1, Jakarta: Salemba Empat.

Suranto. AW. (2007). Komunikasi Efektif untuk Mendukung Kinerja Perkantoran. Yogyakarta: UNY.

Sutanta, Edhy. (2003). System Informasi Manajemen. Yogyakarta: Graha Ilmu

Ulum, Ihyaul. (2012). Audit Sektor Publik Suatu Pengantar. Ed. 1, Cet 2. Jakarta: Bumi Aksara.

Peraturan dan Perundangan:

Pemerintah Republik Indonesia. UndangUndang Nomor 17 Tahun 2003 tentang Keuangan Negara. Jakarta.

Undang-

Undang Republik Indonesia Nomor 1 Tahun 2004. Tentang. Perbendaharaan Negara.Jakarta. 
Undang-

Undang Nomor 23 Tahun 2014 tentang Pemerintahan Daerah. Jakarta.

Peraturan

Pemerintah Nomor 24 Tahun 2005 tentang Standar Akuntansi

Pemerintahan. Jakarta.

Peraturan

Pemerintah Republik Indonesia Nomor 56 Tahun 2005. Tentang. Sistem Informasi Keuangan Daerah. Jakarta.

.Peraturan

Mentri Dalam Negeri 59 tahun 2007 tentang Pengelolaan Keuangan. Jakarta.

Intruksi

Presiden Nomor 3 Tahun 2003 tentang Kebijakan dan Strategi Nasional Pengembangan E-Government. Jakarta.

Peraturan

Menteri Dalam Negeri Nomor 13 Tahun 2006 tentang Pedoman Pengurusan, Pertanggungjawaban dan Pengawasan Keuangan Daerah. Jakarta

Peraturan Menteri Dalam Negeri Nomor 55 Tahun 2008 tentang Penatausahaan dan Penyusunan Laporan Pertanggungjawaban Bendahara Serta Penyampaiannya. Jakarta.

Pemerintah Daerah Kabupaten Blitar. Peraturan Bupati Nomor 30 Tahun 2014 tentang Kebijakan Akuntansi Pemerintah Kabupaten Blitar. Jakarta.

Badan Pengawas Keuangan dan Pembangunan (BPKP), 2013. Akuntansi
Pemerintah Berbasis Akrual : Konsep, Pemikiran, dan Implementasi di Indonesia. Modul. 